\title{
自閉症スペクトラム指数とワーキングメモリ容量の関係：定型発達の 成人における自閉性障害傾向
}

\author{
土田幸男 (北海道大学大学院教育学研究科) \\ 室 橋 春 光 (北海道大学教育学研究院)
}

Relationship between Autism-Spectrum Quotient and working memory capacity: Autistic traits in normally developing adults

\section{Yukio TSUCHIDA (Graduate School of Education, Hokkaido University) Harumitsu MUROHASHI (Faculty of Education, Hokkaido University)}

This study explores the relationship between Autism-Spectrum Quotient (AQ) and working memory (WM) capacity. It has been hypothesized that autism and Asperger Syndrome lie on a continuum of social-communication disabilities. According to the hypothesis, Asperger Syndrome is intermediate between autism and normality. The problem with WM capacity in autism is not in phonological WM, but rather in visuo-spatial WM. A similar pattern of WM capacity can also be observed in normally developing adults with high-AQ scores. Accordingly, this study examines the relationships between AQ in normally developing adults and WM capacities in terms of the phonological loop, the visuo-spatial sketchpad, and the central executive. The results show that a high-AQ group had less capacity for visuo-spatial WM than a low-AQ group. Among all participants, a negative correlation was found between AQ and visuo-spatial WM capacity. However, no differences were observed in the capacities of the phonological loop and the central executive between the high- and low-AQ groups. These results suggest that high-AQ individuals among normally developing adults exhibit a pattern that is a cognitive characteristic of autism.

Key words: autism-spectrum, Autism-Spectrum Quotient (AQ), working memory capacity, visuospatial working memory, phonological working memory

本研究は自閉症スペクトラム指数 $(\mathrm{AQ})$ とワーキングメモリの各コンポーネントが関わる記憶容量との関 係を検討した. 自閉症スペクトラムとは, 自閉性障害の症状は社会的・コミュニケーション障害の連続体上 にあり，アスペルガー症候群は定型発達者と自閉性障害者の中間に位置するという仮説である. 自閉性障害 者においては音韻的ワーキングメモリには問題が見られないが，視空間的ワーキングメモリには問題が見ら れるという報告がある。高い自閉性障害傾向を持つ定型発達の成人のワーキングメモリ容量においても，同 様の傾向が見られる可能性がある。そこで本研究では定型発達の成人において音韻的ワーキングメモリ容量, 視空間ワーキングメモリ容量，そして中央実行系が関わるリーディングスパンテストにより査定される実行 系ワーキングメモリ容量と AQ の関係を検討した。その結果, AQ 高群では低群よりも視空間ワーキングメ モリ容量が小さかった。 全参加者による相関係数でも，AQ と視空間ワーキングメモリ容量の間には負の相 関が認められた。しかし，音韻，実行系ワーキングメモリ容量と AQの間には関係が見られなかった。こ れらの結果は，自閉性障害者で見られる認知特性が，定型発達の成人の自閉性障害傾向で屯同様に関わって いることを示唆している.

キーワード：自閉症スペクトラム, 自閉症スペクトラム指数 $(\mathrm{AQ})$, ワーキングメモリ容量, 視空間ワーキン グメモリ，音韻ワーキングメモリ

\section{序論}

自閉性障害は広汎性発達障害の一つであり, 対人関係 に密接に関連する障害と考えられている. DSM-IVに よれば，「自閉症の基本的特徵は，対人的相互関係およ び意思伝達の著しい異常またはその発達の障害, および
著明に制限された活動と興味の範囲の存在である」とさ れている (American Psychiatric Association, 1994). また，「相互的対人関係における障害は粗大で持続する」 と屯述べられている。 アスペルガー症候群むまた広汎性 発達障害に含まれ，自閉性障害と同じ診断基準に当ては まるが言語の遅れがないものとされている。近年では自 
閉性障害とアスペルガー症候群は社会的・コミュニケー ション障害に関して連続体にあること, またアスペル ガー症候群は自閉性障害と定型発達の中間的存在である という仮説が検討されている(Baron-Cohen, 1995; Frith, 1991). この自閉症スペクトラム仮説は定型発達 者との連続体が仮定されることから，自閉症スペクトラ ム指数 (Autism-Spectrum Quotient: 以下 $\mathrm{AQ}$ 之表 記）を用いて健常範囲の知能を持つ成人の自閉性障害傾 向を測定することができると考えられている (BaronCohen, Wheelwright, Skinner, Martin, \& Clubley, 2001). AQ は日本語版む作成されていて, 定型発達の 成人における自閉性障害傾向の個人差を対象にした研究 の可能性が示唆されている（若林・東條・BaronCohen·Wheelwright, 2004).

自閉性障害は情報処理に特徵があると考えられ, 自閉 性障害における認知機能についてさまざまな研究が行わ れてきている. 自閉性障害では特徵抽出に依存した視覚 的・空間的情報処理においては定型発達者と变わらない か, あるいは優れていると考えられている (Dakin \& Frith, 2005). このような低次の認知機能とは逆に, よ り複雑な高次認知機能では自閉性障害でさまざまな問題 が報告されている（太田，2003）。

自閉性障害の認知機能についての研究では, ワーキン グメモリ（以下 WM と表記）についても数多くの研究 がされている. WM は Baddeley (1986) が提唱した動 的な作業記憶のシステムである. WM は三つのコン ポーネントで構成されている。,一つめは, 音韻情報の貯 蔵や処理に関わる音韻ループである. 二つめは, 視覚情 報の貯蔵や処理に関わる視空間スケッチパッドである. そして，三つめが上記二つのサブコンポーネントを監督 的に管理すると考えられている中央実行系である.これ らの各コンポーネントにはそれぞれ制限のある容量が存 在する. 自閉性障害における WM 成績の報告は一貫し ておらず, 定型発達者より成績が悪いという報告がある 一方, 変わらないという報告も存在する (Ozonoff \& Strayer, 2001; Russo, Flanagan, Iarocci, Berringer, Zelazo, \& Burack, 2007). 自閉性障害者と定型発達者 を対象にした研究では, WAIS-R の数唱得点に違いは なく，符号のように記憶だけでなく異なる特性を実行す る課題の時に干渉を受け成績が悪くなることが報告され ている (Nakahachi, Iwase, Takahashi, Honaga, Sekiyama, Ukai, Ishii, Ishigami, Kajimoto, Yamashita, Hashimoto, Tanii, Shimizu, \& Takeda, 2006). Williams, Goldstein, Carpenter, \& Minshew (2005) の研究では, 高機能自閉性障害者では言語 WM には問題がないが, 空間 WM では問題があるという結果が報告されている. Nakahachi et al. (2006) と Williams et al. (2005)の研 究を考慮すると, 自閉性障害者では言語・音韻 WM 容
量には問題がないが，視空間 WM 容量では問題がある 可能性が考えられる。また単に貯蔵するだけでなく，さ らに実行系の操作が必要な場合の記憶に問題がある可能 性が示唆されている.

音韻ループ, 視空間スケッチパッドといったサブコン ポーネントが関わる WM 容量とは別に, 中央実行系が 関わる WM 容量が存在する.これはリーディングスパ ンテストやオペレーションスパンテストといった，二重 課題で構成されているスパンテストで測定される (Conway, Kane, Bunting, Hambrick, Wilhelm, \& Engle, 2005). リーディングスパンテストでは実験参加 者は呈示された文章を音読しながら文中にある夕ーゲッ 卜語を覚えなくてはならない. 音読が終わるとすぐに次 の試行に移り, 何試行か遂行した後に呈示されたター ゲット語を再生するといった記憶テストになっている. オペレーションスパンテストでは, 実験参加者は呈示さ れた計算式を音読しつつ計算を行い, 示されている解が 正しいかどうか判断しなくてはならない. 計算の解の正 誤判断を行ったらすぐに画面が切り替わり, 実験参加者 は呈示されたターゲット語を音読して覚えなくてはなら ない.これらの試行を何回か遂行した後に呈示された ターゲット語を再生する.これらのスパンテストは数唱 などの古典的な短期記憶課題のように, 内言によって覚 えるべき対象を繰り返して記憶を定着させるリハーサル による記憶の保持が困難である点が特徵として挙げられ る. スパンテストで測定された WM 容量は, Engle, Kane, \& Tuholski (1999) によれば, Baddeley のモデ ルにおける中央実行系の容量制限のある注意メカニズム の能力であるとされている. すなわち，スパンテストで 測定された WM 容量は記憶あるいは貯蔵それ自体につ いての容量ではないと考えられていて, 数唱などで測定 される貯蔵が重視された記憶とは区別されている.

自閉性障害の症状は定型発達者と連続的であるという 自閉症スペクトラム仮説を想定した場合, 定型発達者の 自閉性障害傾向の程度によっても自閉性障害者と同様な 認知パターンを示す可能性が考えられる. 自閉性障害の 連続説を支持する論拠の一つとして, 近年では遺伝研究 などから幅広い表現型という新たな概念も提唱されてい る (Dawson, Webb, Schellenberg, Dager, Friedman, Aylward, \& Richards, 2002; Happé, Ronald, \& Plomin, 2006). すなわち, 自閉性障害の診断基準を満 たさない自閉性障害者の家族においても, 対人関係障害 やコミュニケーション障害といった自閉性障害の諸特徵 の一部が見られる者が多く認められていると報告されて いるのである. Dawson et al. (2002) は自閉性障害を形 ゔくる候補として顔の情報処理, 対人行動や対人的報酬 に対する反応性, 運動の模倣, 記憶, 実行機能, そして 言語能力といった六つの特性を挙げている.これらのよ 
土田・室橋：自閉症スペクトラム指数とワーキングメモリ容量の関係
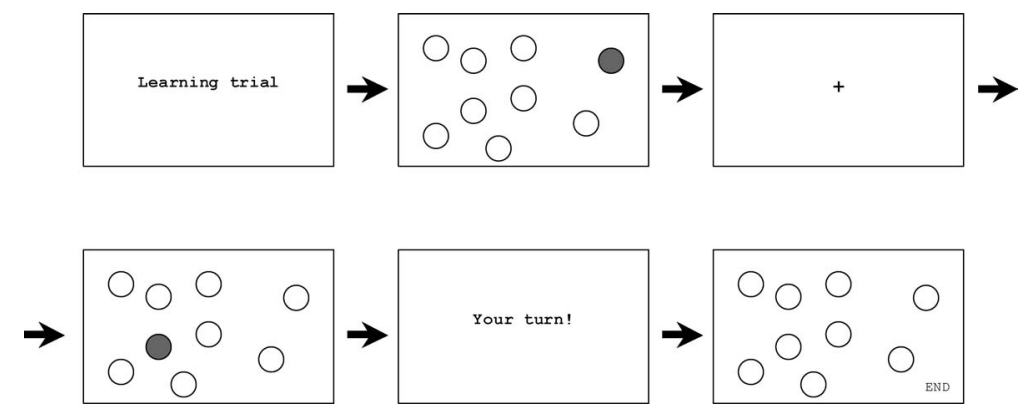

Figure 1. Schema of the visuo-spatial test.

うな特性が，自閉性障害の診断基準には満たないが $\mathrm{AQ}$ 得点の高い者にも認められる可能性がある。本研究では 連続説を支持する立場で, 認知心理学的な WM の観点 からの検討を行った。

自閉性障害が連続的であると考えた場合, 定型発達者 の自閉性障害傾向を示す $\mathrm{AQ}$ 得点の個人差は, 自閉性 障害での認知特性と関係が見られる可能性がある。自閉 性障害者では音韻 WM 容量には問題が見られないが, 視空間 WM 容量には問題が見られるという乘離が，定 型発達者の $\mathrm{AQ}$ 得点の高低にも反映されるかもしれな い。すなわち, $\mathrm{AQ}$ 得点が高い者ほよ゙視空間 $\mathrm{WM}$ 容量 が小さく, 音韻 WM 容量には違いがないという可能性 である。また，自閉性障害の症状は実行系機能の問題で あるという仮説が存在する (Ozonoff, Pennington, \& Rogers, 1991; Ozonoff, Strayer, McMahon, \& Filloux, 1994). 中央実行系の容量を反映するスパンテス トにより測定された WM 容量（本研究では実行系 WM 容量とする）む $\mathrm{AQ}$ 得点之関係する可能性がある. 本 研究では自閉症スペクトラム仮説の立場に基づき, 定型 発達の成人の $\mathrm{AQ}$ 得点とこれらの各 $\mathrm{WM}$ コンポーネン 卜の記憶容量がどのような関係を持つか検討した。

\section{方法}

実験参加者 参加者は 18 歳から 33 歳までの大学 生・大学院生 56 名 (平均 23.5 歳, $S D=3.37$, 男性 27 名, 女性 29 名) であった。すざての参加者がイン フォームドコンセントに同意して実験に参加した．参加 報酬として 500 円分の図書カードを与えた。

自閉性障害傾向質問紙 自閉性障害の傾向を測定する, AQ 日本語版（若林ら，2004）を実施した。各項目は 50 項目からなり, 自閉性障害の傾向を示す問いに対し “あてはまる”，“どちらかといえばあてはまる”、“どち らかといえばあてはまらない”，そして“あてはまらな い”の 4 肢選択で回答させた.

記憶テスト 実行系 WM 容量を測定するテストとし
てリーディングスパンテスト（艼阪，2002）を実施し た。音韻 WM 容量を測定するテストとしては WAIS-R 数唱の順唱を用いた (Wechsler, 1997). 視空間 WM 容 量を測定するテストとして，Visuo-spatial testを作成 し実施した。Visuo-spatial test 実施中の一連の流れを Figure 1 に示す. Visuo-spatial test は, ノートパソコ ンで実施し, 学習試行と回答試行の二つのパートから なった。 学習試行では, “learning trial” の文字の後に, 画面に九つに九つの丸を呈示した. 九つの丸のうち一つ が赤くなり, その後凝視点が表れ, また九つの丸のうち 一つが赤くなるようにした．参加者には赤くなった丸の 順序之場所を正確に覚えるように教示した。 これを何回 か繰り返した後, 画面に “your turn!” の文字を呈示し, 参加者に回答を求めた。回答は学習試行で赤くなった順 序で丸を正確にクリックしていき, 学習試行で呈示され た順序でクリックし終えたら画面右下にある “END”を 押し試行を終了させた，九つの丸の配置は試行ごとに変 わり, 丸の位置は乱数で割り当てて作成された。刺激の 持続時間は 1,000 ms とした. Visuo-spatial test の問 題数は順唱と同じとした。丸を覚える数は三つから始ま り，2 試行で構成された。 三つを覚える試行が 2 回終了 したら四つを覚える試行となり, 最終的には九つを覚え る試行とした。

手続き 実験参加者に各記憶テストをランダムな順序 で実施した。記憶テストがすべて終わった後に，AQを 実施した。

分析方法 リーディングスパンテストの得点化方法は 艼阪 (2002) の手続きにならった。 2 文から 5 文まで 5 試行が繰り返されるが， 3 試行以上正しく再生できた最 大の文の数によって評価を決定した. 3 試行は正しく再 生できなかったが，2 試行は正しく再生した場合は 0.5 点をそれまで再生できた最大の文の数に加え得点化した。 順唱とVisuo-spatial test は正しい順序で再生できた総 数を得点とした.

AQ 得点は若林ら (2004) と同様の方法で得点化した. 
Table 1

Characteristics of the high- and low-AQ groups

\begin{tabular}{|c|c|c|c|c|c|c|}
\hline \multirow[b]{2}{*}{ Group } & \multicolumn{2}{|c|}{ Gender } & \multicolumn{2}{|c|}{ Age } & \multicolumn{2}{|c|}{ AQ score } \\
\hline & Female & Male & $M$ & $S D$ & $M$ & $S D$ \\
\hline High-AQ $(n=12)$ & 3 & 9 & 23.5 & 3.50 & 27.42 & 3.90 \\
\hline Low-AQ $(n=12)$ & 9 & 3 & 23.5 & 3.71 & 8.08 & 2.87 \\
\hline
\end{tabular}

各項目の自閉性障害傾向を示す側に“あてはまる”また は“どちらかといえばあてはまる”（逆転項目では“あ てはまらない”または“どちらかといえばあてはまらな い”）という回答に 1 点を与えて総得点を算出した. 全 参加者 56 名のうち $\mathrm{AQ}$ 得点の上位 $1 / 4$ に相当する 12 名を $\mathrm{AQ}$ 高群, $\mathrm{AQ}$ 得点の下位 $1 / 4$ に相当する 12 名を $\mathrm{AQ}$ 低群とした。

本研究に扮ける $\mathrm{AQ}$ 高・低群は, 今回の実験参加者 内での相対的比較のために設けたものであり，AQ高群 が臨床診断に相当することを意味するあのではない。し かしながら, 定型発達者においても自閉性障害傾向は連 続的であり, $\mathrm{AQ}$ 高群は自閉性障害者の持つ認知特性と 類似したパターンを示し， $\mathrm{AQ}$ 低群は異なるパターンを 示す可能性が考えられる。

\section{結果}

$\mathrm{AQ}$ 全参加者における $\mathrm{AQ}$ 得点は 3 から 38 の範囲 であった. カットオフポイントである 33 点を超えてい た者は 1 名で, 臨床的診断を受けてはいなかった. Table 1 に各群の特性を示す。平均得点は $17.16, S D$ は 7.23 であった。

記憶テスト AQ 高・低群ごとのテスト得点の結果を Figure 2 に示す. AQ 高・低群で各 WM テスト得点が 異なるかどうか 2 要因分散分析を行った（AQ 群 $\times W M$ テスト課題の種類). その結果, WM テストの主効果は 有意だが $(F(2,44)=146.00, p<.001), \mathrm{AQ}$ 群の主効果は 統計的に有意ではなかった. WM テストと $\mathrm{AQ}$ 群の間 には有意な交互作用が見られた $(F(2,44)=3.22, p<$ .05). 単純主効果の検定を行ったところ, Visuo-spatial test 得点において AQ 群の効果が見られた $(F(1,22)=$ $5.14, p<.05)$. AQ 高群は低群よりも視空間 WM 容量 が小さかった.

相関係数 56 名の全実験参加者を対象に, $\mathrm{AQ}$ 得点 と各 WM テスト間の相関係数を算出した (Table 2). $\mathrm{AQ}$ 得点とリーディングスパンテスト，順唱の間に統計 的に有意な相関は見られなかった。一方, $\mathrm{AQ}$ 得点と Visuo-spatial test 得点の間には統計的に有意な負の相 関が見られた $(r=-.37, p<.01) . \mathrm{AQ}$ 得点が高い者ほよ゙ 視空間 WM 容量が低いことが全実験参加者を通しても

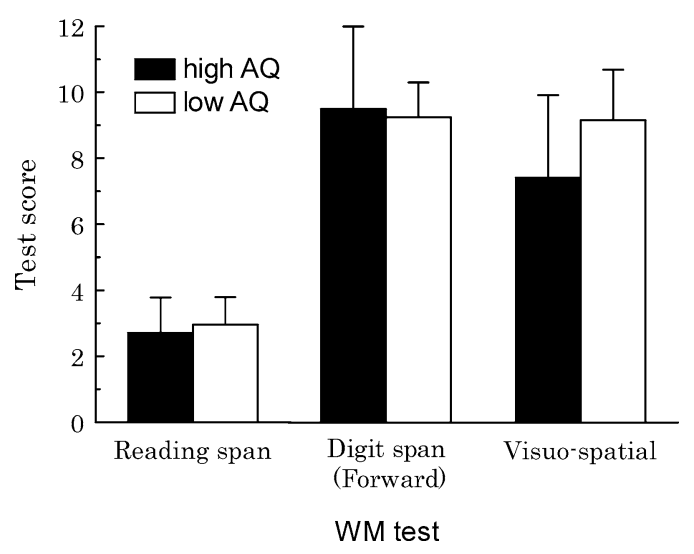

Figure 2. Mean score (and $S D$ ) of each working memory test by the high-and low-AQ groups.

Table 2

Correlation coefficients between total AQ and each working memory score

\begin{tabular}{|c|c|c|c|}
\hline & Reading span & $\begin{array}{c}\text { Digit span } \\
\text { (Forward) }\end{array}$ & Visuo-spatial \\
\hline Total AQ & -.15 & -.00 & $-.37^{* *}$ \\
\hline
\end{tabular}

確認された.

\section{考察}

本研究では自閉症スペクトラム仮説に基づき, 定型発 達の成人において, 自閉性障害傾向を測定する $\mathrm{AQ}$ 得 点の個人差が各 WM コンポーネントである中央実行系, 音韻ループ, そして視空間スケッチパッドの容量とどの ような関係を持つか検討した。

$\mathrm{AQ}$ 得点の高群と低群では, 視空間 WM 容量のみ違 いが見られ，音韻 WM, 実行系 WM 容量では差が見ら れなかった。 AQ高群のほうが低群よりも視空間 WM 容量が小さかった。このことは全参加者での相関係数で も確認された。この結果はWilliams et al. (2005)の結 
土田・室橋：自閉症スペクトラム指数とワーキングメモリ容量の関係

果と対応している，彼女らの研究では高機能自閉性障害 者を対象にしており，言語 WM 容量では高機能自閉性 障害者と定型発達者で違いが見られないが，空間 WM 容量では高機能自閉性障害者のほうが定型発達者よりも 成績が低かったことを報告している。 Williams et al. (2005) の言語 WM は本研究の音韻 WM 容量に対応し, 空間 WM は視空間 WM と対応している。このような 高機能自閉性障害者で見られる音韻 WM と視空間 WM 容量の乘離が，定型発達者を対象にした自閉性障害傾向 の個人差でも再現された。自閉性障害者で見られる認知 特性が，定型発達者に抢ける自閉性障害傾向においても 存在することを示唆している.

視空間 $\mathrm{WM}$ 容量は $\mathrm{AQ}$ 低群よりも高群のほうが小さ かった，本研究では $\mathrm{AQ}$ 高・低群の男女比が異なって いるが，このことが視覚 WM 容量の違いに影響した可 能性はあるのだろうか. Wechsler (1987) によれば，視 覚性記憶範囲課題を含めたWMS-R の下位検査項目の 成績に男女差は見られていない。また本研究においても 男性と女性で視空間 WM 容量に統計的な違いはなかっ た $(t=.66, p=.51)$.これらのことから, 本研究に打ける $\mathrm{AQ}$ 得点之視空間 WM 容量の関係は性差それ自体の効 果によるあのではなく, 自閉性障害傾向に関わる要因に よるあのだと考えられる。

実行系機能むまた自閉性障害の問題之深く関わる機能 と考えられている（太田, 2003; Ozonoff et al., 1991; Ozonoff et al., 1994; Russo et al., 2007). 本研究では 中央実行系の容量を測定するためリーディングスパンテ ストを実施し， $\mathrm{AQ}$ 得点との関係を検討した。しかしな がら, AQ 高群と低群で実行系 WM 容量に違いは見ら れなかった。リーディングスパンテストやオペレーショ ンスパンテストは中央実行系機能を反映していると考え られているが(Conway et al., 2005; Engle et al., 1999), 実行系機能は多岐にわたっている. Miyake, Friedman, Emerson, Witzki, Howerter, \& Wager (2000) では, 実行系機能を Shifting, Inhibition, そして Updating の三つに分類している。 スパンテストは Updating に関 わっているが，自閉性障害者で成績の低下が報告されて いるウィスコンシンカードソーティングテストやハノイ の塔など (Ozonoff et al., 1991; Bennetto, Pennington, \& Rogers, 1996; Ozonoff \& Jensen, 1999) は，それぞ れ Shifting と Inhibition が関わっていると考えられて いる. Russo et al. (2007) は自閉性障害に㧍ける実行系 機能は Inhibitionには問題がないが Shifting のような 認知的柔軟性が関わる機能には問題があると報告してい る。また，彼女らは自閉性障害者の Updating に関して， 短期記憶容量には問題があるものの, 干渉課題を伴う記 憶課題では差が見られないことをレビューしている。こ の干渉課題は Inhibition が関わっていると述べられて
いる. リーディングスパンテストは Updating 機能が関 わっていると考えられるが, Inhibition, なかでも優勢 反応抑制機能む関わっている (Kane \& Engle, 2003) と いう報告あある. このため, Inhibition に問題がないと される自閉性障害者の研究と, 本研究のリーディングス パンテストと $\mathrm{AQ}$ 得点の間に関係が見られなかったこ とは対応している可能性がある.

本研究では $\mathrm{AQ}$ 得点の個人差之視空間 $\mathrm{WM}$ の間に関 係が見られた。本研究では定型発達の成人について $\mathrm{AQ}$ 高・低群に分けて検討したが， あくまであ今回の実験参 加者内での相対的分類であり, 実際の自閉性障害者を対 象とした検討むまた必要である.

\section{結論}

本研究では定型発達の成人に打ける自閉症スペクトラ ム指数 (AQ) 得点の個人差と, WM のコンポーネントで ある中央実行系, 音韻ループ, そして視空間スケッチ パッドの容量の関係を検討した。実行系, 音韻 WM 容 量之 $\mathrm{AQ}$ 得点の間に関係は見られなかったが, 視空間 $\mathrm{WM}$ 容量は $\mathrm{AQ}$ 得点が高いほど小さいという結果が示 された。自閉性障害者では音韻 WM 容量には問題が見 られないが視空間 WM 容量には問題があるという乘離 は, 定型発達の成人における自閉性障害傾向の違いにお いても再現された。この結果は, 自閉性障害者で見られ る認知特性が, 定型発達の成人に抢ける自閉性障害傾向 に扔いても同様に存在していることを示唆している.

\section{引用文献}

American Psychiatric Association (1994). Diagnostic and statistical manual of mental disorders. 4th ed. Washington, D. C.

Baddeley, A. D. (1986). Working memory. New York: Oxford University Press.

Baron-Cohen, S. (1995). Mindblindness: An essay on autism and theory of mind. Boston: MIT Press-Bradford Books.

Baron-Cohen, S., Wheelwright, S., Skinner, R., Martin, J., \& Clubley, E. (2001). The AutismSpectrum Quotient (AQ): Evidence from Asperger Syndrome/High-Functioning Autism, Males and Females, Scientists and Mathematicians. Journal of Autism and Developmental Disorders, 31, 5-17.

Bennetto, L., Pennington, B. F., \& Rogers, S. J. (1996). Intact and impaired memory functions in autism. Child Development, 67, 1816-1835.

Conway, A. R. A., Kane, M. J., Bunting, M. F., 
Hambrick, D. Z., Wilhelm, O., \& Engle, R. W. (2005). Working memory span tasks: A methodological review and user's guide. Psyconomic Bulletin \& Review, 12, 769-786.

Dakin, S., \& Frith, U. (2005). Vagaries of visual perception in autism. Neuron, 48, 497-507.

Dawson, G., Webb, S., Schellenberg, G. D., Dager, S., Friedman, S., Aylward, E., \& Richards, T. (2002). Defining the broader phenotype of autism: Genetic, brain, and behavioral perspectives. Development and Psychopathology, 14, 581-611.

Engle, R. W., Kane, M. J., \& Tuholski, S. W. (1999). Individual differences in working memory capacity and what they tell us about controlled attention, general fluid intelligence and functions of the prefrontal cortex. In A. Miyake \& P. Shah (Eds.), Models of working memory: Mechanisms of active maintenance and executive control. New York: Cambridge University Press. pp. 102-134.

Frith, U. (1991). Autism and Asperger's syndrome. Cambridge: Cambridge University Press.

Happé, F., Ronald, A., \& Plomin, R. (2006). Time to give up on a single explanation for autism. Nature Neuroscience, 9, 1218-1220.

Kane, M. J., \& Engle, R. W. (2003). Workingmemory capacity and the control of attention: The contributions of goal neglect, response competition, and task set to Stroop interference. Journal of Experimental Psychology: General, 132, 47-70.

Miyake, A., Friedman, N.P., Emerson, M. J., Witzki, A. H., Howerter, A., \& Wager, T. D. (2000). The unity and diversity of executive functions and their contributions to complex "frontal lobe" tasks: A latent variable analysis. Cognitive Psychology, 41, 49100.

Nakahachi, T., Iwase, M., Takahashi, H., Honaga, E., Sekiyama, R., Ukai, S., Ishii, R., Ishigami, W., Kajimoto, O., Yamashita, K., Hashimoto, R., Tanii, H., Shimizu, A., \& Takeda, M. (2006). Discrepancy of performance among working memory related tasks in autism spectrum disorders was caused by task characteristics, apart from working memory, which could interfere with task execution. Psychiatry and Clinical Neurosciences, 60, 312-318.

太田昌孝 (2003). 自閉性障害圈障害における実行 系機能 高木隆郎・P. ハウリン・E. フォンボン (編) 自閉性障害と発達障害研究の進歩 星和書 店 pp. 3-25.

苧阪満里子 (2002). 脳のメモ帳 ワーキングメモ リ 新曜社.

Ozonoff, S., \& Jensen, J. (1999). Brief report: Specific executive function profiles in three neurodevelopmental disorders. Journal of Autism and Developmental Disorders, 29, 171-177.

Ozonoff, S., Pennington, B. F., \& Rogers, S. J. (1991). Executive function deficits in highfunctioning autistic individuals: Relationship to theory of mind. Journal of Child Psychology and Psychiatry, 32, 1081-1105.

Ozonoff, S., \& Strayer, D. L. (2001). Further evidence of intact working memory in autism. Journal of Autism and Developmental Disorders, 31, 257-263.

Ozonoff, S., Strayer, D. L., McMahon, W. M., \& Filloux, F. (1994). Executive function abilities in autism and Tourette syndrome: An information processing approach. Journal of Child Psychology and Psychiatry, 35, 10151032.

Russo, N., Flanagan, T., Iarocci, G., Berringer, D., Zelazo, P. D., \& Burack, J. A. (2007). Deconstructing executive deficits among persons with autism: Implications for cognitive neuroscience. Brain and Cognition, 65, 77-86.

若林明雄 - 東條吉邦 - Baron-Cohen, S. - Wheelwright, S. (2004). 自閉性障害スペクトラム指 数 $(\mathrm{AQ})$ 日本語版の標準化一一高機能臨床群之 健常成人による検討 心理学研究，75, 78-84.

Wechsler, D. (1997). Wechsler Adult Intelligence Scale. 3rd ed. San Antonio, TX: The Psychological Corporation.

Wechsler, D. (1987). Wechsler Memory Scale Revised. San Antonio, TX: The Psychological Corporation. (杉下守弘 (訳著) (2001). 日本版ウエクスラー記憶検査法 WMS-R 日本 
土田・室橋：自閉症スペクトラム指数とワーキングメモリ容量の関係

文化科学社).

Williams, D. L., Goldstein, G., Carpenter, P. A., \& Minshew, N. J. (2005). Verbal and spatial working memory in autism. Journal of Autism and Developmental Disorders, 35, $747-756$.
World Health Organization (1992). ICD-10. International classification of diseases. 10 th ed. Geneva, Switzerland: World Health Organization.

（2008 年 6 月 3 日受稿, 2009 年 5 月 8 日受理) 